\title{
Choreographic Art in the Far Eastern Federal District: History, Problems and Prospects of Development
}

\author{
Irina E. Eres'ko* \\ Khabarovsk State Institute of Culture \\ 112 Krasnorechenskaya Str., Khabarovsk, 680045, Russia
}

Received 20.11.2016, received in revised form 18.02.2016, accepted 28.02.2016

The article deals with contemporary choreographic amateur work in the Far Eastern Federal District in the context of the history of the national choreographic art development. The author refers to the characteristics of the main directions and genres, analyzes the work of choreographic festivals, competitions, creative activities and the repertoire of choreographic groups of the region.

Keywords: choreography, dance, ballet, amateur performance, folklore.

DOI: 10.17516/1997-1370-2016-9-6-1369-1375.

Research area: art history.

Modern amateur choreographic performance exists in different genres and unites participants into the groups of different directions. These are dance companies and studios of folk, classical and pop dance, folk ballet theatres, groups of sport and forms of contemporary dance, different associations of ballroom choreography lovers, etc. In addition, national and folk groups of peoples that live in the territory of the Far Eastern Federal District.

Nowadays, there are some researchers' attempts to refer to the experience of the choreographic performances development, in particular in the Far Eastern Federal District. Its history has not been written, the artistic significance of its best works, choreographers, teachers and dancers' activities, as well as new forms and directions have not been assessed.
Some information can be obtained in the works on the history of the related arts: theater, music and performance, which development was in contact with choreography. That is why articles and reviews of the contemporary researches that can be found in bulletins, documents, as well as personal participation in methodological work, participation in and organization of festivals, seminars, competitions and communication with the managers and team member are the most valuable materials.

Considering choreography development in the Far Eastern Federal District, it should be noted that it has been developing in accordance with the historical events of our country. The works of researchers on the history of both professional and amateur choreographic art emphasize that folk dance performance in Russia

(C) Siberian Federal University. All rights reserved

* Corresponding author E-mail address: Tanais2@mail.ru 
has a long history. Even in pre-Christian Russia merrymaking, accompanied by dances and round dances was widely spread. Buffoonery is an original, unique phenomenon of Russian artistic culture that has had a huge impact on the formation and development of theater, music, vocal and choreographic art in Russia. Peter's Assemblies the first public balls in Russia that became history - instilled the tradition of everyday dancing as an integral part of the Russian people's upbringing and education (Klimov, 1981).

J. von Staehelin characterizes the late $19^{\text {th }}$ - early $20^{\text {th }}$ century amateur dance performance of the nobility and bourgeoisie by creation of and dancing ballets. This direction of amateur choreographic art is almost entirely focused on the professional ballet theatre copying. These years are remarkable by opening in the capitals and major cities of Russia of a large number of dance schools and studios, amateur and semiprofessional, driven by different motivations. Most of them appeared under the influence of new artistic systems - "free dance" of Isadora Duncan and "rhythmic education" of Jacques Dalcroze. Folk choreography manifested itself in folk dancers' performances in pop divertissements and theatrical performances for the working class viewers.

October Socialist Revolution clearly marked a boundary not only in the civil history, but also in the history of art. The objectives to raise educational and cultural level of people and inclusion of the masses to the values of art declared by the new government were expressed in the grandiose national theatrical performances and meetings-concerts. Dance, along with the music, singing and word became an integral part of these grandiose celebrations. In the first years after the revolution there were a large number of dance studios that promoted the ideas of "free" dance, rythmoplastics, pantomime dance, gymnastics and acrobatics. Along with that, the studios continued to focus on professional art, thus in the diversity of their searches they were in parallel with the searches of a young Soviet ballet.

According to T.V.Purtova, the 30 s became the period of the Soviet choreographic art formation on the amateur stage, the period of discoveries and creation of new, previously unknown forms of existence, types and genres of dance art that determined the paths of its development for the coming decades (Purtova, 2006). By the mid 30 s the Soviet choreographic art had a new full-fledged form of existence - amateur groups of several kinds. There was introduction and inclusion of the general public to choreography, dance lovers training, identifying the most talented ones, development of various kinds of dance - classical, pop, sports and character dance, there were attempts to create their own repertoire, the process of mutual influence and enrichment from the achievements of choreographic art on the professional stage took place. At this time dance shows, festivals and competitions were held. The development of the art of dance was actively supported by the state and patronized by master choreographers. It should be noted that the Houses of People's Art established in the 30's became the form of methodological assistance of choreographic amateur performance. Their tasks included advanced training of the group leaders, providing repertoire and teaching aids.

During the war dance amateur performance continued to be one of the most important parts of the cultural and educational work. The Red Army dance occupied the main place in its repertoire. In the rear and at the front line the participants of dance groups took part in the performances of concert brigades that were created by the professional dancers and singers.

Analyzing the stages of choreographic amateur art, T.V. Purtova notes that to the second half of the century amateur choreographic 

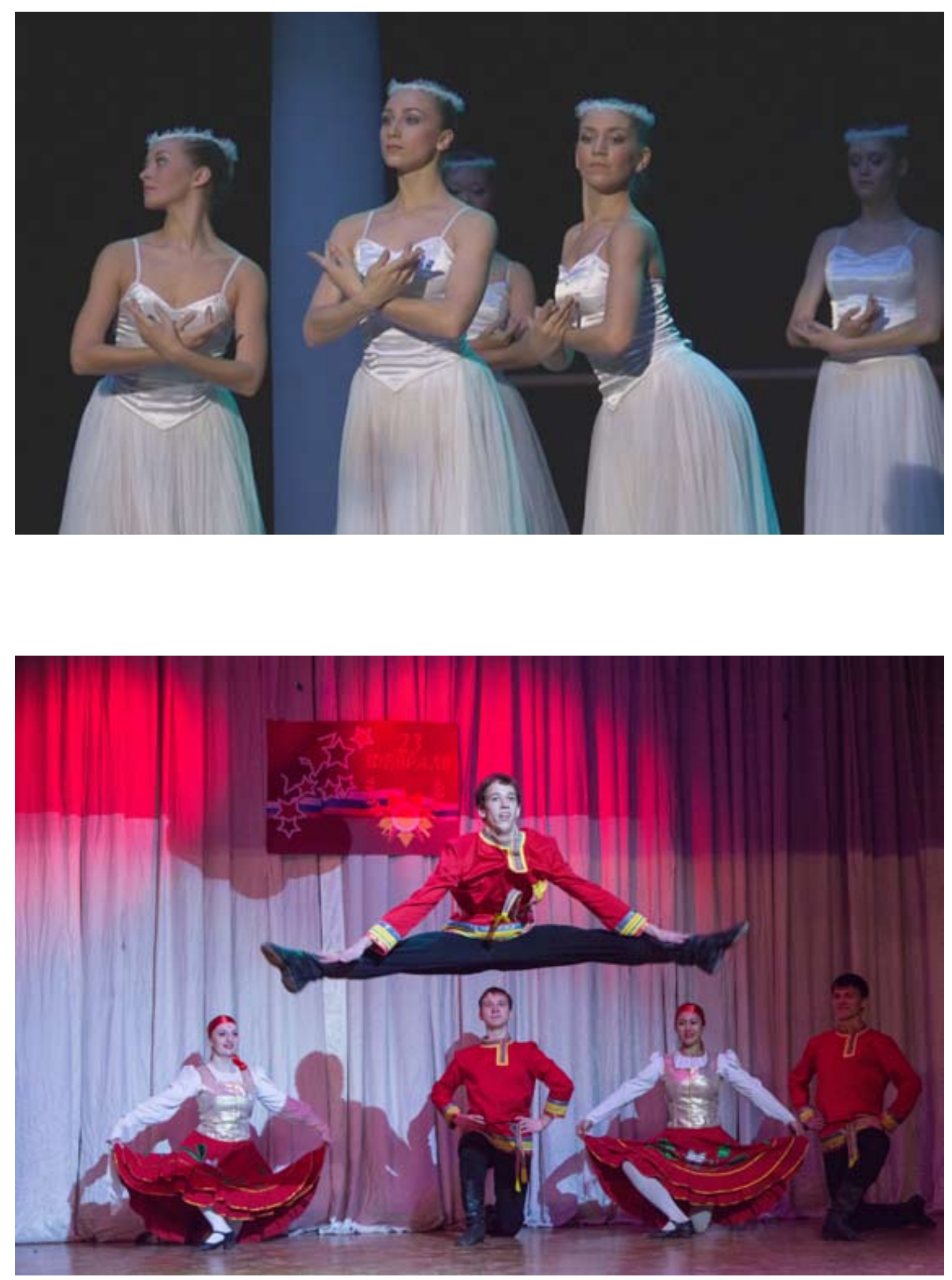
performance was formed into an artistic phenomenon of many components, working a controversial and complicated way from dance studio experiments to the foundation of groups and then folk dance ensembles and appearance of ballet dance performances on the amateur stage (Purtova, 2006). Dance amateur performance had several forms: choreographic clubs for children of different ages and adults, folk dance ensembles, classical dance studios and individual folk ballet theaters, ballroom and pop dance studios and ensembles. A form of large-scale music and dance shows, gala concerts to the anniversaries, World Festivals of Youth and Students became popular again.

It should be noted that in the $60 \mathrm{~s}$ a system of training for managers and teachers of choreographic amateur performances started its establishment. Choreographic profile started to appear in the institutes of culture and cultural and educational schools. Moscow Institute of Culture was one of the first that started choreographic groups' managers training. Later, choreographic departments were established in Leningrad, Chelyabinsk, Kemerovo, Krasnodar, Ulan-Ude and Khabarovsk, as well as in the capitals of the Union republics.

Analyzing choreographic amateur art of the late 20th century, it should be noted that democratic changes that took place in the USSR in the second half of the $80 \mathrm{~s}$, radically influenced further development of the amateur art in Russia. Choreographic amateur performance turns to the revival of folk traditions and experiments in the modern dance genres. Professional recommendations substitute clear ideological orientations in the shows and contests provisions. The terms are: to represent a folk dance on the material of your region or on the material of dance folklore of the Soviet peoples or peoples of the world; story composition that reflects the modern youth theme; chamber dance composition (with the number of participants not more than 5 persons).

By the end of the 80 s under the influence of changes in political life, amateur performance gradually lost its ideological patronage, but at the same time, it lost stable government funding. Choreographers turned to genuine folklore.

The end of the century was a period of searches and experiments. New ways of Russian dance interpretation appeared. These were dances performed by youth folk groups, original stage adaptations, a large number of "flax" performances that use themes and plastics of the Old Russian folklore, performed by the groups of different genres: folk, classical, pop dance, demiclassic and modern.

Modern, "contemporary dance" started its active development. With its appearance and development "contemporary dance" protested both against the existing forms of social and cultural life in general, and the established types and material of choreographic art in particular. The most talented combined traditions and innovations, consolidated choreographic searches of a new plasticity with a bright theatricality.

There appeared pop dance groups that genre affiliation was difficult to classify. Most of these groups lacked style.

At the same time, some choreographers staged performances in line with the language of jazz dance, modern dance and free plastic arts. Russian folk choreography became more significant. At that modern dance, jazz dance, demi-classic and neo-classics in the amateur scene interpretation were not too different from each other.

Since the late 80 s children's art schools started their development. In addition to the educational process, choreographic departments aimed for concert activity. Ensembles, studios, schools and classic dance theaters represented the main directions of: "classical dance" (mainly 
the patterns of the classical heritage) and the original leaders' staging set to the classical or contemporary music with the use of demi-classic lexis, free plastics and classical dance.

Considering amateur choreographic performance in the Far Eastern Federal District at present, it is necessary to identify the main directions and genres that develop especially actively. We have analyzed choreography festivals, competitions, creative activity and repertoire of the dance groups in the region.

At present, the groups of folk and modern dance, as well as pop and ballroom dance groups are actively developing. Classical dance groups are underrepresented. The so-called modern "street dance directions" are developing.

The Far Eastern Federal District includes Khabarovsk Krai, Magadan Oblast, Chukotka Autonomous District, the Republic of Sakha (Yakutia), Primorsky Krai, Amur Oblast, Sakhalin Oblast, Kamchatka Territory and the Jewish Autonomous Region.

Russians, Ukrainians, Evenks, Evens, Belarusians, Tatars, Nanai, Koryaks, Chukchi, Eskimos, Koreans, Yakuts, Itelmens and Jews live here.

In the late $20^{\text {th }}$ - early $21^{\text {st }}$ century the traditional art of the indigenous peoples of the Far East that came from the life of the distant past continues to preserve and develop. Ensembles from Yakutia, Chukotka and Kamchatka create original dance theater sketches on the basis of folklore.

Contemporary choreographic art of the peoples of the Far East is characterized by close interweaving of the traditional folk arts of dancing, amateur performance and professional performing arts. The repertoire of the amateur song and dance ensembles of the indigenous population of Chukotka and Kamchatka is renovated by new dances. They are based on folk material, but they have developed music and dance scores and are enriched by modern themes and theatrical forms of expression. In the process of creating new lexical material of choreographic compositions, traditional plastic means of depicting the images of people, animals and separate items are used. National ensembles interact with professional groups: the State Chukchi-Eskimo ensemble "Ergyron", Koryak national ensemble "Mengo", ensemble "Nulgur" from Kamchatka Krai, etc. Regularly held competitions and art festivals, seminars and master classes contribute to the development of amateur and professional art of the peoples of Far East. New projects and grants appear, such as "School of the National Art of the Peoples of Kamchatka", which has been providing training and meetings of managers and teams involved in the national culture of the peoples of the Far East for four years.

Choreographic groups of the Jewish Autonomous Region represent national peculiarity and regional differences of Jewish folk dances.

Some groups of Sakhalin Oblast represent the culture, traditions and the variety of Korean folk dance. Against this background, dance groups and folk dance ensembles that represent Russian dance in their repertoire, mostly copy the dances of professional ensembles.

Development and creation of new folk groups in the Far Eastern Federal District should be mentioned. Besides, there is an active cooperation with Asia Pacific countries. Creative trips of various ensembles to People's Republic of China, South Korea and Japan, as well as international competitions contribute to the study and inclusion to the traditions and dance culture of Asian countries.

Analyzing competitions of the Far Eastern Federal District, we unfortunately see a few classical dance groups. They are mostly children's groups, they represent choreography schools and arts schools, or student groups of colleges and Institute of Arts and Culture. There is no 
national ballet theater. Whole ballet shows are mostly performed by students. "Classical Dance" category at the competitions is mainly represented by the $9-12$ years age category.

The most numerous categories at the competitions are represented by "Modern" and "Pop" dance. Special festivals of contemporary dance are held. Analyzing the development of these choreography genres in the region, it should be noted that against the background of numerous groups, which repertoires are not characterized by conception clarity, depth of music comprehension and the desire for its organic expression through the language of choreography, a lot of leaders, gripping at the external form, create compositions sometimes to the detriment of the dance art originality (especially in children's groups). It is possible to separate individual choreographers who create compositions that are notable for their theatricality, creating a dance performance staged in a certain style.

Pop dance is represented by children's and youth groups. Youth dance groups represent a wide variety of forms, types of pop dance and modern directions. Most often fusion of different styles and directions takes place. It can be a popstyled folk or ballroom dance, free plastics, "rock dance", "step", etc.

Studying festival movement in the Far Eastern Federal District, it should be noted that the number of contestants has increased as well as the number of participants. Thus, the most significant major competitions in Khabarovsk are: International Festival "Rhythms of the Planet", Far Eastern Regional Competition of Choreographers, Regional Festival of Choreographic Art "Dance Kaleidoscope" and Festival of Choreographic Art "Smile of childhood". Contests and festivals of genre orientation: Festival of Classical Dance "Brilliant Divertissements" and Far Eastern Regional Competition of Modern Choreography "DailDiesel". Student Competition of
Choreographer Works increased its status to the International Competition of Choreographer Works "Games of the Imagination", which founders are Khabarovsk State Institute of Arts and Culture and Ministry of Culture of the Russian Federation. In general, the competitions have increased in the number of participants and groups and genre orientation. Competition "Game of Imagination" is a choreographer's competition and is oriented both to mass and solo dances staging in various categories. Compositions of larger scale are represented in the competition: modern miniatures and ballets. A new performing category "Dance Virtuoso" appeared where the members of the jury assess skills and technique of both individual performers and mass choreographic compositions in various categories. The competition is focused on the development of choreographic thinking and imagination of both young choreographer-students of secondary and high schools and experienced choreographers. This is an experimental platform that allows to identify stage fantasy and new young talents among the youth.

If we analyze the quantitative and qualitative composition of the choreographic groups of the Far Eastern Federal District, after the recession in the early 80 s, the number of shows, competitions and festivals, as well as the number of groups and participants, the present situation is more stable. It should be noted that the increase in the number of children's dance groups throughout the territory of the Far Eastern Federal District is obvious. But at the same time, a decrease in the number of participants in adult dance groups worth mentioning. According to the age composition children's groups dominate $-66.4 \%$ of the total number. Adult groups comprise $19.8 \%$ and mixed composition of the participants is observed in $13.8 \%$ (according to the data from Scientific and Analytical Center KNOTOK, Khabarovsk, 2003). 
Summing up, we can emphasize that the last decade of our country history has shown the demand for choreographic direction of our culture. Choreographic amateur art remains attractive both to children and young people in the Far Eastern Federal District. Modern amateur art fills the leisure time of the Far Eastern Federal District residents with the active performance, provides artistic and aesthetic, musical and choreographic education to children. The system of professional teachers and choreographers training, educationalcreative and repertoire aid, the established system of competitions and festivals have led to the qualitative changes in the development of dance creativity on the amateur stage. Careful attitude towards the national culture of the indigenous peoples of the Far Eastern Federal District should be noted. Mutual influence and enrichment of dance cultures of the Far Eastern Federal District leads to the search for and development of the authentic samples of folk dance art, preservation and passing of choreographic traditions, distinctive lexical material of the peoples living in this territory.

Thus, today's objectives of professional choreographers of amateur direction is improvement of the modern forms of amateur choreographic art, restoring ties between the traditional dance performance, innovative experiments on the amateur stage and professional choreographic art.

\title{
References
}

Purtova, T.V. [2006]. Tanets na liubitel'skoi stsene [Dance on Amateur Stage], In XX vek: dostizheniia i problemy [The 20 ${ }^{\text {th }}$ Century: Achievements and Challenges]. M., GRDNT, 168.

Klimov, A.A. [1981]. Osnovy russkogo narodnogo tantsa [Basics of Russian Folk Dance]. M., Iskusstvo, 18-19.

\section{Хореографическое искусство в Дальневосточном регионе: история, проблемы, перспективы развития}

\author{
И.Е. Ересько \\ Хабаровский государственный институт культуры \\ Россия, 680045, Хабаровск, ул. Краснореченская, 112
}

\begin{abstract}
В статье рассматривается современное хореографическое любительское творчество в Дальневосточном регионе в контексте истории развития отечественного хореографического искусства. Автор обращается к характеристике основных направлений и жанров, анализирует работу хореографических фестивалей, конкурсов, творческую деятельность и репертуар хореографических коллективов региона.
\end{abstract}

Ключевые слова: хореография, танец, балет, самодеятельность, фольклор.

Научная специальность: 17.00.00-искусствоведение. 